\title{
A Meaningful Academic Life: Loving, Fulfilling, Challenging, and Flabbergasting
}

\begin{abstract}
In this essay, I present the talk I gave at the celebration honoring my retirement from University of South Florida (USF). Held on January 25, 2019, this event was attended by an audience of friends, students, and university faculty and administrators. I tell several stories about coming to USF, meeting and collaborating with Art Bochner, and the support I experienced and the fulfillment I found in my university life. Passionate about teaching from the heart to the whole person and doing research that matters, I describe the meaning I derived from participating in an interpretive and qualitative Communication program that focused on the human sciences. I end with 10 aphorisms or observations from lessons learned in my experience of four decades in the university, some of which allude to the unnamed challenges I experienced among the great joys and good fortune of academic life.
\end{abstract}

Keywords: Academic life, academic calling, meaning and membership, retirement, academic aphorisms.

\section{Znaczące życie akademickie: pełne miłości, satysfakcji, wyzwań i oszałamiające}

\begin{abstract}
Abstrakt
Prezentowany esej odwołuje się do przemówienia, które Carolyn Ellis wygłosiła $\mathrm{z}$ okazji przejścia na emeryturę po kilkudziesięciu latach pracy $\mathrm{w}$ Uniwersytecie Południowej Florydy. W wydarzeniu, które odbyło się 25 stycznia 2019 r., brali udział przyjaciele, studenci, a także pracownicy naukowi i władze uczelni. Profesor Ellis opowiedziała kilka historii o swoich początkach na uniwersytecie, ważnych, formujących spotkaniach oraz o współpracy z Arthurem Bochnerem. Tekst, podobnie jak przemówienie, zawiera także wspomnienie o wsparciu, którego doświadczyła,
\end{abstract}

* Distinguished University Professor Emeritus, Department of Communication, University of South Florida. 
spełnieniu, które znalazła w życiu uniwersyteckim, pasji nauczania płynącej z serca, skupionej w całości na drugiej osobie oraz prowadzonych badaniach, będących istotą pracy na uczelni. Profesor Ellis opisuje również korzyści z uczestnictwa w programie studiów w zakresie jakościowej i ilościowej analizy komunikacji społecznej z uwzględnieniem humanistycznej perspektywy. Tekst kończy się dziesięcioma aforyzmami lub obserwacjami z lekcji wyniesionych z doświadczenia ponad czterech dekad spędzonych na uniwersytecie, wśród których znalazły się zarówno niewypowiedziane wyzwania, jak i wielkie radości oraz momenty szczęścia.

Słowa kluczowe: życie akademickie, wezwanie profesjonalne, znaczenie i uczestnictwo, przejście na emeryturę, uniwersyteckie aforyzmy.

I am delighted to be at this celebration and I thank Chair Patrice Buzzanell, Dean Eric Eisenberg, and the College of Arts and Sciences at University of South Florida (USF) for organizing this event in honor of our retirement. Thanks to all of you who have taken time out of your busy day on a Friday afternoon to be here.

Given that I am a storyteller, I want to start with a tale about my first visit to USF. It's called "Eat More Possum."

\section{Eat More Possum}

"So, hey, did folks coon hunt in those mountains you grew up in?" Dean Northcutt asks, as he swivels around in his big leather desk chair, now facing me with what looks like my curriculum vitae in his hands. His face is framed by a balding head, long sideburns, and a double chin.

I have to admit, I am a bit flabbergasted. Certainly, this is not the first question I expected to be asked in a tenure track faculty job interview by the Dean of the College. But his friendly eyes dilute any intimidation his gruff voice might have otherwise engendered in me.

So putting aside my recently acquired New York style of speaking, I call up my country mountain upbringing and respond with my best southern accent-the one I had devoted considerable effort to getting rid of during graduate school at Stony Brook University in New York. ${ }^{1}$ "Oh yea--h, lots of people hunted coons where I grew up. My boyfriend's father-a banker-lived on a farm and he had six coonhounds. He'd hunt all night and then go out at day light to round up the dogs. Those dogs would get mighty excited when he'd put on his camouflage gear, get his night light, and blow into his coon caller."

\footnotetext{
${ }^{1}$ I grew up in Luray, Virginia, a town of three thousand people in the Shenandoah Valley, surrounded by the Blue Ridge Mountains. After receiving my undergraduate degree in Sociology at the College of William and Mary, I worked for a year as a social worker. Then I attended Stony Brook University from 1974-1981, when I obtained my PhD in Sociology.
} 
The Dean chews thoughtfully on the smashed wet end of his unlit Cuban cigar. "Nothin' like coon huntin'," he says. He nods several times, and so I nod too. "Lots of moonshine in those mountains, yeah?"

"Sure was," I respond. "My father used to work at a still. He'd often bring moonshine home and drink it out of a pint jar. That's some stron--g stuff."

The dean continues to nod, and a big smile breaks out on his face. "Lots of turkey farms there too, yeah?"

"Yes," I respond. I really want this job, and now I feel comfortable trying my hand at some local color. "We used to have turkey oyster parties. Do you know what they are?"

"Of course," he says, without skipping a beat. "Some mighty fine eatin', those fried turkey testicles." He catches my eye, and not knowing what else to say, I smile and nod again.

As I was leaving campus later that day, I saw an old beat up 1963 Ford pickup in the parking spot reserved for the Dean. On the back was a bumper sticker that read, "Eat more opossum."

That interaction was my introduction to USF in the fall of 1980. In 1981, when I was thirty and USF was barely 21 , I became a faculty member in the Sociology Department, composed mostly of older white men, many of whom were hired by a telephone call-sight and vita unseen. The Department had never tenured a woman, much less a minority; I would be the first woman to earn tenure there. Needless to say, there were some challenges. One of my most vivid memories is when a colleague demanded, "I've invited in a speaker. And I'm depending on you to get together all those little cakes and cookies, like you always do, and make them look real pretty now." Showing resistance, I failed to perform my hostess tasks.

For the first year in my position, I really missed my progressive feminist graduate student colleagues from New York. But thankfully there were many newly hired young women in other departments, so I had plenty of like-minded company. Thankfully, I grew quite fond of my male colleagues in Sociology.

I want to fast forward now to 1996. But first, there's a background story from January 1990 that I want to tell. Ah, yes. In January 1990, I met Art Bochner.

This story is called Academic Flirting.

\section{Academic Flirting}

[This story is performed by Carolyn and Art. Art speaks his part seated in his chair on the stage while Carolyn stands at the podium.]

Art [Picks up school newspaper in his office, and turns to his student]: Look, there's a talk being given in the Business School today entitled "Systematic Sociological Introspection and Research on Emotions." The author is Carolyn Ellis from the Sociology Department. Um, I've never heard of her, but the topic sounds intriguing. Let's go. 
Carolyn: And in conclusion, what I've done in this presentation is to lay out how one might use a systematic, scientific form of sociological introspection to try to understand the intersection of personal and social aspects of emotions. In Final Negotiations about the illness and death of my partner, Gene Weinstein, I have tried to show what narrative written from introspection might look like-a story with a plot, character development, scenes, and action, which invite you to enter our experience with us, feel what we feel, or imagine what you might feel or have felt in similar circumstances. In that way, you have your own emotions to examine, the best way I know to convey to you how emotions feel.

Now I'd like to open up this session for questions from the audience. Yes... [Pointing toward Art]

Art [Stands and raises his hand; Carolyn nods]: Dr. Ellis, I really appreciated your talk. Social science does indeed need more heart and emotion. I have only one small point to raise. You seem to accept the terms that orthodox social scientists use to describe their work-objectivity, validity, reliability. This ends up making you sound very defensive. Why not drop all the science talk? It only distracts you and your readers from the very human sense of suffering and loss you communicate so beautifully ... [Pause] and another question I have ... [Art sits]

Carolyn: And that's how we met. I wondered who this man saying all these things could be. His questions were interesting, though I couldn't help but think he was one of those "language is everything people." Anyway, I was accustomed to defending myself against the accusation that what I was doing wasn't science and I had expected to get that critique in the Business School. But this guy was coming at me from a whole new angle: Why are you being so defensive about your work as science? Certainly, it gave me a lot to think about. Besides I also was fascinated with how good looking he was. Who IS this person anyway?

Art: I sat in amazement listening to Carolyn talk. I realized how similar she was to me in the way she described what needed to be done to resurrect the social sciences and make them meaningful. I thought, she's giving my talk. Who IS this woman anyway? How could we have been on the same campus for the last six years and never met?

Of course, the truth is I was immediately attracted to her passion and energy and the way she danced around the floor (to say nothing of her good looks). I couldn't help wondering: Is she available? Is she still mourning the loss of her partner? I thought I ought to at least go up and meet her, and feel out the possibilities. So I waited until the crowd around her dissipated and I introduced myself. We walked out of the room talking and into the parking lot together, talking some more.

Carolyn: Art and I decided to exchange articles we'd published. On Monday, I had a student run some things across campus to Art's mailbox. That day and the next, every time I went to my mailbox, I had another article from Art. Sometimes only an hour apart. "Hm," I thought, "this is definitely an academic form of 
flirtation." So I wrote him a note thanking him for the articles, and added, "I'm certainly glad we found each other." That was my form of flirtation.

Art and Carolyn [In unison]: And as the saying goes, one thing led to another.

Carolyn: And we've been talking together ever since. As Art likes to say,

Art: "Talk is the kiss of life."

What followed that meeting were years of collaboration characterized by good fortune-and some challenges-at USF and in the Department of Communication.

\section{A Fulfilling Life in Communication and at USF}

In 1996, I moved from Sociology to the Communication Department. That move was a difficult decision, but I now think that everyone should change departments in the middle of their careers. That transition certainly broadened my perspective and helped me to see what I do in new and different ways. Immediately, from the beginning, I felt accepted and rewarded in the discipline of Communication, especially professionally. Though I missed Sociology and all my friends and colleagues there, and I will always think of myself as a sociologist, I have been fully rooted in Communication for the last twenty-three years.

The Department I joined in 1996 was an exciting place. Really, I could barely contain myself at my good fortune of being in an interpretive, qualitative, performative, critical and interdisciplinary department; one that celebrated the humanities side of the discipline; one that Art, as chair, had shepherded with his colleagues. It was everything I hoped and dreamed it would be. In our heyday, Eric Eisenberg, Elizabeth Bell, Ken Cissna, Stacy Holman Jones, and many others were part of this thriving niche program. The graduate students came hungry for and passionate about ethnography, autoethnography, and storytelling. There was nothing like it, really, anywhere in the world.

Certainly there were challenges, some flabbergasting ones (see Ellis, in press), but all in all the last twenty-plus years were a wonderful and meaningful time, when Art and I often didn't know when we were working and when we were just living and enjoying life together.

I also had the good fortune of loving teaching. In my undergraduate classes on writing lives, storytelling, emotions, and grief and loss, my goal has been to provide a supportive, safe, and caring place where students can write through their life problems that lie unresolved and often stand in their way. Being part of a class where students have breakthroughs; where they discover they are not alone, and that though they are unique, they also are one among many; where they come to understand difference though the stories told, listened to, and discussed; where they learn to write and live a new story... well, that has been one of my greatest joys. As David Brooks (2019) says, students learn best in positive emotional relationships. They respond when you teach to the whole person, provide a loving 
space, and take into account their emotions, bodies, and spirit as well as their brains. The same has been true of graduate students, and even more so because they also embraced, and expanded, the methods, philosophy, values, and way of life we were advocating.

As I get used to retirement (or "permanent sabbatical" as we like to call it), not much in my life has changed. Well, I don't get a paycheck! That's different. I don't go to faculty meetings! I don't get embroiled in department politics. I don't have to grade or listen to complaints from students. I no longer feel I have to defend what I do or what I think. But already I miss the kind of energy that can be generated in a graduate classroom: the lively exchange of ideas, the passion and excitement that builds through the semester, the stimulating conversations that have us on the edge of our seats; the happy exhaustion on the ride home and talking to Art over a late dinner about what happened in class that day. What an honor and a privilege to have been a part of graduate education.

Of course, there are many other opportunities to create that liveliness. Many of our closest friends and colleagues are our former students-some of them are here today-so we continue those exchanges, now focusing on their careers instead of ours. We do many teaching workshops around the world. Moreover, there are always manuscripts and book proposals to read; reference letters, external dissertation reviews, papers and books to write; and conferences to attend. Life continues to feel engaged and full.

Thankfully the talk around the dinner table continues just as before where Art and I are not sure when work ends and the rest of our lives begins. Together, we create a new chapter where talk is still the kiss of life. And now, rather than rushing off in military lockstep to the next obligation, and then the next, there is more precious time to linger in conversation, enjoy the moment and the beauty of the world around us, and plan the next new adventure.

\section{Aphorisms for My Students and Colleagues}

As a closing note, I leave you now with 10 aphorisms or observations from lessons learned in my experience of more than forty years of teaching, research, and service. Some of them point to the challenges I experienced as bewildering among the great joys and good fortune of academic life. I hope that they are helpful to you, as you navigate your careers in the university.

1. Institutions have no loyalty and no memory. Believing that has kept me from making many bad decisions.

2. We all teach ourselves and we do it best through our contagious passion for our subjects and students (Brooks 2019).

3. In general, faculty have problems with communication, even those in Communication Departments. 
4. No matter how similar a group of faculty are, they will create major differences about which to disagree. Departments are similar to dysfunctional families, but often without the familial ties that might bring the members back together.

5. Don't expect your colleagues to celebrate your successes; if you do, you will be sorely disappointed.

6. Just as you couldn't wait for your senior colleagues to leave when you were a young professor, don't expect the younger and upcoming faculty in your department to treat you as a wise elder now. They probably won't.

7. The secret to sanity is to exaggerate the goodness of the world (Henry 1971).

8. No matter how good a program or idea is, it will have only a certain life span, then some group will seek to change it.

9. Thus, a second secret to sanity is to adapt to change and realize that everyone, including you, can and will be replaced. Everything ends.

10. Don't take yourself too seriously.

Last, in spite of the challenges in departmental life alluded to in these aphorisms, I want to thank the University of South Florida for being open to new and different ideas, for giving me a bundle of opportunities and rewards, and supporting my life's work and passion along the way. In many ways, we have grown up together. For me, being a university professor is one of the most meaningful callings in the world. I can't imagine having spent this part of my life any other way, and I will be forever grateful.

\section{References}

Brooks D. (2019) Students Learn from People They Love: Putting Relationship Quality at the Center of Education, "The New York Times" (January 17), https://www. nytimes.com/2019/01/17/opinion/learning-emotion-education.html

Ellis C. (in press) Failing to Communicate in a Communication Department: A Former Chair Calls Her Spirit Back in: D. (2019) Students Learn from People They Love: Putting Relationship Quality at the Center Critical Administration: Negotiating Political Commitment and Managerial Practice in Contemporary Higher Education, W. Benjamin Myers, J. Brower (Eds.), Lanham Md., Lexington Books.

Henry J. (1971) Pathways to Madness, New York, Vintage Books. 